\title{
Volcanic monitoring and hazard assessment in El Salvador
}

\author{
Rodolfo Castro*, Eduardo Gutiérrez \\ Direccion del Observatorio de Amenazas y Recursos Naturales, \\ Ministerio del Medio Ambiente y Recursos Naturales (MARN), El Salvador.
}

\begin{abstract}
The Salvadorean volcanic range forms part of Central America Volcanic Arc and is located on the Pacific ring of fire. El Salvador is a country with at least twenty Holocene-active volcanic structures and where most of the population, including the metropolitan area of San Salvador, live near a volcanic complex. Currently, there are six active volcanoes that are continuously monitored by the Observatorio de Amenazas y Recursos Naturales, which is part of the Ministerio del Medio Ambiente y Recursos Naturales. Volcano monitoring involves seismic, geochemical, and visual monitoring techniques, among others. In addition to volcano monitoring and with the aim of early warning of future eruptions, volcanic hazard maps and networks of local observers have been developed. These initiatives together with the general directorate of civil protection, seek to meet the goal of reducing risk from volcanic activity in El Salvador.
\end{abstract}

Este artículo está disponible en español: https://doi.org/10.30909/vol.04.S1.183201 [PDF ES].

\section{InTRODUCTION}

El Salvador belongs to the Circum-Pacific belt. The volcanic range that crosses the county from west to east, parallel to the coast forms part of the Central America Volcanic Range (CAVA) and the origin of volcanism in the country is related to the subduction of the Cocos Plate below the Caribbean Plate, which generates intense seismicity and partial melting of the Earth's mantle. The generated magma rises through the Caribbean Plate along fracture networks to the surface, where volcanic eruptions and the formation of volcanic structures take place. The result of this process, that takes several thousands of years [Bosse et al. 1976], is the formation of the volcanic axis that crosses the entire country. More than $90 \%$ of the national subsurface consists of Cenozoic and Quaternary volcanic materials [MeyerAbich 1956; Bosse et al. 1976; Kattan et al. 2017].

\subsection{Active volcanism in El Salvador}

According to the Global Volcanism Program [2013] [see also Siebert et al. 2011], there are 20 volcanoes in El Salvador that have been active during the Holocene (Table 1). Among these, 6 volcanoes are considered active due to recent activity within the last 500 years or their current fumarolic activity [Kattan et al. 2017; MARN 2019a], and are systematically monitored. These are, from west to east: Izalco, Santa Ana, San Salvador, Ilopango, San Vicente, and San Miguel volcanoes (Figure 1). Izalco (1950 m.a.s.l.), Santa Ana (2381 m.a.s.l.), San Salvador (1890 m.a.s.l.), San Vicente (2182 m.a.s.l.), and San Miguel (2130 m.a.s.l.) are stratovolcanoes

\footnotetext{
*Corresponding author: rodolfo.a.castro@gmail.com
}

of basaltic-andesitic to andesitic composition while Ilopango is a large caldera structure (13 by $17 \mathrm{~km})$ and has a rhyodacitic composition.

Santa Ana and San Miguel volcanoes last erupted in October 2005 and December 2013, respectively. Santa Ana volcano is characterized by frequent phreatomagmatic activity. During its last eruption (October 5, 2005), ballistics fell up to $2.5 \mathrm{~km}$ away from the crater, pyroclastic surges affected the eastern slope of the volcano, post-eruptive lahars affected the shore of Lake Coatepeque and 1.5 million $\mathrm{m}^{3}$ of ash was emitted, affecting some nearby towns and roads. San Miguel volcano typically erupts in a strombolian style, which in its last major eruptive episode (December 29, 2013) ejected ballistics up to $2.5 \mathrm{~km}$ away from the crater, produced a $7.6 \mathrm{~km}$ high column of ash and a volume of $850000 \mathrm{~m}^{3}$ of ash mostly affecting flora and fauna near the crater. Izalco volcano, the youngest volcano of El Salvador, began its construction in the 18th century and is characterized by Strombolian and effusive activity. Its last eruption was in 1966. San Salvador volcano last erupted in 1917, with a Strombolian-type eruption that constructed the Boqueroncito scoria cone, emitted ash on the SW slope of the volcano and lava flow [Ferrés 2014]. Ilopango caldera is, perhaps, the most powerful and dangerous volcano of El Salvador, with Plinian, phreatomagmatic, and effusive activity in its eruptive history [Pedrazzi et al. 2019]; its last eruption generated the dacitic Islas Quemadas dome in 1879-1880. The last eruption of San Vicente is unknown, however its current activity is fumarolic. At this point, it is necessary to remember the importance of developing geological and volcanological studies in order to have a clear idea of the stratigraphy and the eruptive history of volcanoes. 
Table 1: Volcanoes in El Salvador that have been active throughout the Holocene [Global Volcanism Program 2020].

\begin{tabular}{lll}
\hline \multicolumn{1}{c}{ Volcano Name } & Primary Volcano Type & Last Known Eruption \\
\hline Chingo & Stratovolcano & Unknown \\
San Diego & Volcanic field & Unknown \\
Singuil, Cerro & Pyroclastic cone(s) & Unknown \\
Apaneca Range & Stratovolcano(es) & Unknown \\
Santa Ana & Stratovolcano & 2005 C.E. \\
Izalco & Stratovolcano & 1966 C.E. \\
Coatepeque Caldera & Caldera & Unknown \\
San Salvador & Stratovolcano & 1917 C.E. \\
Cinotepeque, Cerro & Volcanic field & Unknown \\
Guazapa & Stratovolcano & Unknown \\
Ilopango & Caldera & 1880 C.E. \\
San Vicente & Stratovolcano & Unknown \\
Apastepeque Field & Volcanic field & Unknown \\
Taburete & Stratovolcano & Unknown \\
Tecapa & Stratovolcano & Unknown \\
Usulutan & Stratovolcano & Unknown \\
Tigre & Stratovolcano & Unknown \\
Chinameca & Stratovolcano & Unknown \\
San Miguel & Stratovolcano & 2020 C.E. \\
Aramuaca, Laguna & Maar & Unknown \\
\hline
\end{tabular}

It is estimated that about 2 million people (approximately $30 \%$ of the total population of the country) live in the areas surrounding these active volcanoes and are therefore exposed to different volcanic hazards. Of these, more than 1.5 million are concentrated in the metropolitan area of San Salvador (2007 Census) that includes, in addition to the capital city, 13 municipalities near to the volcanic complex of San Salvador and the Ilopango Caldera (Figure 1).

\subsection{Dirección General del Observatorio de Amenazas y Recursos Naturales (DOA): the volcano monitoring institution of El Salvador}

The National Geological Service was established in 1955 as a department of the public work ministry. Its director was Dr. Helmut Meyer-Abich, a German geologist working on seismic instrumentation for seismic monitoring [Meyer-Abich 1956]. Later in 1964, by executive agreement, the Servicio Geológico Nacional and the Laboratory and Experimental Section were joined to create the Centro de Investigaciones Geotécnicas (CIG). This was a secondary unit of the public work ministry, improving on research, professional staff and work tools. From 1967 to 1971, the Salvadorean geological map was developed in collaboration with the German geological mission and the CIG. Some years later, the Ministerio de Medio Ambiente y Recursos Naturales (MARN) was founded in May 1997 (executive order No. 27) as a product of Article 117 of the Republic of El
Salvador constitution, which states: "It is the duty of the State to protect natural resources, as well as diversity and integrity of the environment, to guarantee sustainable development". The Servicio Nacional de Estudios Territoriales (SNET) was created in 2001 as a scientific institution affiliated with MARN. The SNET was created in response to crisis generated by the January and February 2001 earthquakes and the need to strengthen the scientific-technical institutions in charge of monitoring and evaluating natural phenomena and hazards. It includes CIG staff and departments (notably the geology, seismology, and volcanology departments), the meteorological and hydrological services (which had been previously part of the Minesteria de Agricultura), and a new department for risk management. In 2007 the SNET adopted the same organization chart structure as a directorate of MARN and changed their name to Dirección General del Observatorio Ambiental (DGOA). In 2011, the Centro de Monitoreo Integrado de Amenazas Naturales was created as part of DGOA, where volcanic surveillance is currently carried out 24/7 together with seismological, landslide, hydrological and meteorological surveillance. Years later, in May 2016, a number of responsibilities of MARN were redefined (agreement No. 139):

1. To develop scientific research and specialized studies for uses related to risk prevention and reduction, both in the field of disasters and land-use planning and to transfer the results of investigations and studies to responsible government agen- 


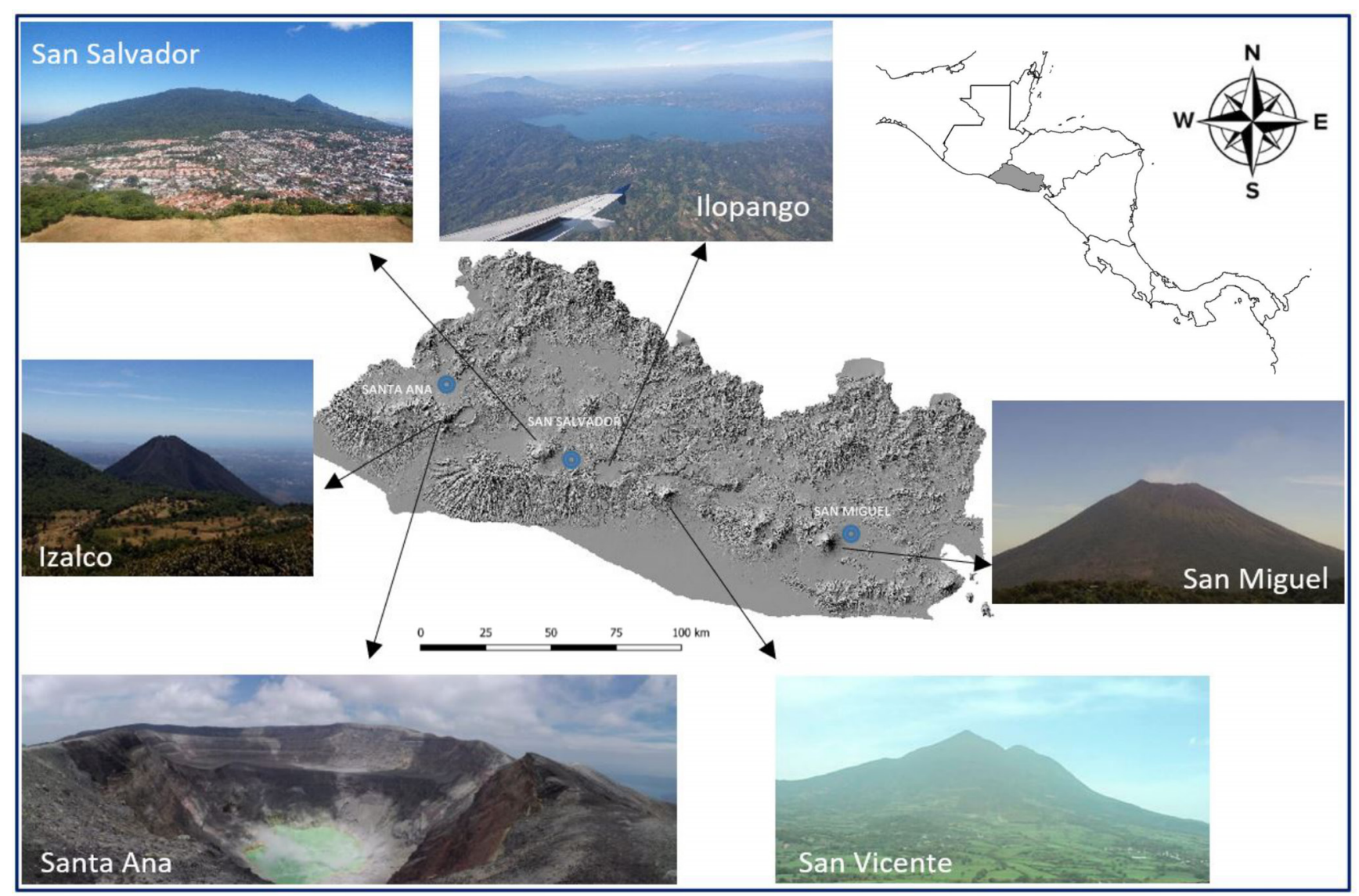

Figure 1: Location of the six monitored actives volcanoes of El Salvador and location of the main cities. The Background is a hillshade map by MARN [2019a]. Images of Ilopango Caldera (December 2016), San Salvador volcano (November 2017), Izalco volcano (February 2016) and Santa Ana volcano (March 2018) by R. Castro. Image of San Vicente volcano (July 2018) by M.A. Serra; and the image of San Miguel volcano taken by the webcam owned by MARN in February 2020.

cies, so that each one executes the recommendations according to their capacity.

2. To deploy instrumentation and carry out systematic monitoring of meteorological, hydrological, seismological, volcanic and geotechnical processes and phenomena for alert purposes.

3. To validate and disseminate information in a timely and efficient manner to the authorities and the population in general, about threats and vulnerable conditions whose magnitude and importance can be translated into losses and damages.

4. Constrain the territoriality of impacts of hazardous phenomena and processes, as well as the probable nature of losses and damages.

5. To provide scientific and technical support for the design, installation and operation of Early Warning Systems, in coordination with other competent institutions and agencies.

In the last restructuring of MARN, that took place in 2019, DGOA changed its denomination to Dirección General del Observatorio de Amenazas y Recursos
Naturales (DOA), and currently includes the Integrated Monitoring Center. Since its establishment, the DOA has worked with national and international partner and collaborating organizations (e.g. universities, agencies, NGOs, geological services), especially with the Dirección General de Protección Civil in order to issue early warnings of natural hazards.

\section{HOW DO WE MONITOR THESE VOLCANOES?}

To date (in 2020), the staff in charge of research and volcano monitoring at MARN is composed of 14 persons. These include three experts in volcanology and one geologist, with the permanent support of five technical experts in seismic monitoring and five technicians specialized in geological hazard monitoring. Personnel at the observatory carry out continuous monitoring in two shifts of 10 and 14 hours per day, 365 days of the year.

The main parameters monitored to identify changes in the activity of Salvadoran volcanoes are: seismic activity, direct measurements on volcanic plumes and gases released through the ground (quantity and 
composition), chemistry of the water (lakes, lagoons, springs and wells) and ground deformation [MARN 2019b]. Table 2 shows the techniques used at each of the six monitored volcanoes. Santa Ana, San Salvador and San Miguel volcanoes have the highest level of instrumentation because of their recent elevated activity and risk level [MARN 2019a]. See maps of the monitoring network distribution in Figure 2.

The volcano monitoring strategy at MARN involves various techniques including permanent stations and punctual measurement during field campaigns:

1. Seismic monitoring: seismometers are deployed around volcanoes (since 1984 for San Salvador volcano and since 2002 for the other monitored volcanoes) in order to record seismic signals associated with rock fracture and fluid movement. Instrumentation consists of networks of telemetric seismic stations (14 accelerographs, 4 broadband and 18 short period). If necessary, during an eruptive crisis or when some equipment is damaged, portable stations can also be installed. As of 2019, monitoring duties include daily counts of the different types of recorded signals, automatic classification of volcanic seismic signals using Repeating Earthquake Detector [REDPy; Hotovec-Ellis and Jeffries 2016], and Real-time Seismic-Amplitude Measurement (RSAM) alarm to detect frequency changes.

2. Geochemical monitoring: as of 2018 , in-field gas data collection is carried out annually at every monitored volcano, where $\mathrm{H}, \mathrm{SO}_{2}, \mathrm{CO}_{2}, \mathrm{H}_{2} \mathrm{~S}$ measurements are performed using a MultiGAS apparatus Since 2008, $\mathrm{SO}_{2}$ emissions have been continuously measured at San Miguel and Santa Ana volcanoes using Differential Optical Absorption Sepctroscopy (DOAS). During field campaigns, fumarole temperatures are monitored using thermocouples and infrared cameras. Additionally, hydrogeochemical monitoring is carried out at the six monitored volcanoes by performing temperature and $\mathrm{pH}$ measurements and composition analysis (chlorides, sulfates, etc.) of the waters associated with the volcanic complexes. The samples are taken from lagoons, springs or wells near the volcanoes and processed at the laboratory facilities at MARN.

3. Deformation monitoring: since 2006, ground deformation has been monitored using GPS stations. Currently, there are 5 permanent GPS stations at San Salvador and San Miguel volcanoes. Monitoring is complemented by measurement campaigns using mobile GPS on fixed positions during crises or if some additional research is needed.

4. Visual monitoring: observations of volcano morphology are carried out during field campaigns. This includes observation of the cone and crater, description of hillside instability phenomena and measurement of the opening of cracks inside the craters. In addition, there are networks (for all the monitored volcanoes) of previously trained local observers composed of residents of the areas near the volcanoes who provide information about changes in the activity and the morphology of the volcanoes. Furthermore, there are two webcams, located at Santa Ana and San Miguel volcanoes, that have been livestreaming since 2006; a third webcam will soon be operational at San Salvador volcano.

Volcano monitoring data is complemented by the collection of meteorological data for areas surrounding these volcanoes (e.g., rainfall and wind). All the recorded data are stored on computers at the DOA and available for research purposes upon request. However, a better database structure is needed as well for future improvement.

\section{VOLCANO HAZARD MANAGEMENT}

MARN has developed an action protocol that serves as a tool and guide for hazard management activities for every stage of volcanic activity, including determining what communication tools (i.e. bulletins, reports, community messages) can be employed and how often they should be produced and updated. This unique protocol includes thresholds or baselines of measured parameters (e.g. RSAM and $\mathrm{SO}_{2}$ ) established from statistical analysis and systematic monitoring of all the active volcanoes.

It is important to mention that there is an enormous amount of work being performed by the volcanology department staff in cooperation with universities and other local and international institutions, including Universidad Nacional Autónoma de Mexico (UNAM), University of Palermo (UNIPA), United States Geological Survey (USGS), . These collaborations pertain to hazard management and focus mainly on the development of hazard maps and volcanological studies devoted to the reconstruction of the eruptive history of the main active volcanoes.

There are volcanic hazard maps for four of the six active volcanoes: Santa Ana volcano, San Salvador volcano, San Vicente volcano and San Miguel volcano. In 1990s, the CIG- part of Ministerio de Obras Públicas (MOP)-was in charge of creating the first volcanic hazard maps in El Salvador [Jimenez et al. 2018]. Later, the USGS produced hazard maps for San Miguel, San Salvador, and San Vicente volcanoes [Major et al. 2001a; b; c]. More recently, complete maps have been produced for San Miguel volcano by Escobar et al. [2004], for Santa Ana volcano by Ferrés et al. [2004] and for San Salvador volcano by Ferrés et al. [2013] and Ferrés [2014], using ASHFALL [Hurst 1994], BALLISTIC [Alatorre-Ibargüengoitia 2003; 
Table 2: Stations/equipment per techniques at monitored active volcanoes of El Salvador. $A=$ accelerograph; $B B=$ broadband; DOAS = differential optical absorption spectroscopy; $M G=$ multiGas; $S P=$ short period; $W C=$ webcam. Seismic stations, DOAS, WC, and GPS are permanent, hydrogeochemical measurements are performed during field campaigns $(\bullet)$.

\begin{tabular}{lcccccc}
\hline Monitoring Techniques & Santa Ana & Izalco & San Salvador & Ilopango Caldera & San Vicente & San Miguel \\
\hline Seismic & 1 BB & 3 SP & $7 \mathrm{AP}$ & $1 \mathrm{~A}$ & $1 \mathrm{~A}$ & $1 \mathrm{BB}$ \\
& $1 \mathrm{DOAS}$ & - & - & $3 \mathrm{SP}$ & $3 \mathrm{SP}$ & $4 \mathrm{SP}$ \\
Gas geochemistry & MG & MG & MG & - & - & $1 \mathrm{DOAS}$ \\
Hydrogeochemistry & $\bullet$ & - & - & - & $\mathrm{MG}$ & $\mathrm{MG}$ \\
Visual & $1 \mathrm{WC}$ & - & - & - & - & $\bullet$ \\
GPS & - & - & 3 & - & - & $1 \mathrm{WC}$ \\
\hline
\end{tabular}

Alatorre-Ibargüengoitia and Delgado-Granados 2006], TITAN 2D [Pitman et al. 2003; GMFG 2007], and FLOW 3D [Malin and Sheridan 1982].

Figure 3 shows some of the available hazard maps. These maps are either constructed by combining various hazards (Figure 3A) or specifically for an individual hazard at different scale (Figure 3B-D). Some of them show general scenarios for all volcanic activity, while others show the areas that can be affected by an individual hazard. There are hazard maps for lava flows, pyroclastic flows (Figure 3A, C), lahars and ballistics fall (Figure 3B, D). Some hazard maps were created for different scenarios (possibility of occurrence) according to previous activity and using a deterministic approach. Currently other hazard maps are being prepared for Santa Ana volcano, San Salvador volcano and San Miguel volcano, using probabilistic approaches [Jimenez et al. 2018]. All the official volcanic hazards maps are found on the official webpage*. According to the classification of the volcanic risk level and after an assessment of hazard and exposure factors, San Salvador and Santa Ana volcanoes represent a very high risk level and, Ilopango caldera and San Miguel volcano, a high risk level [MARN 2019a].

\section{INFORMATION DISSEMINATION AND OUT- REACH}

Communication of volcanic activity is achieved through monthly (or daily, if necessary) reports that are transmitted by fax and radio to civil protection and the national emergency system. This information is also published on the MARM website ${ }^{\dagger}$ and on MARN's social media accounts ${ }^{\ddagger}$. Public live streaming of webcam footage for San Miguel volcano and Santa Ana volcano (El Salvador's most active volcanoes) is available at https://www. youtube. com/c/MARNsv/videos. Constant communication with local observer networks

\footnotetext{
*http://wwW. snet.gob.sv/ver/vulcanologia/amenaza/

$\dagger_{\text {www }}$ marn.gob.sv

$\ddagger_{\text {https: //wWw. facebook. com/MedioAmbienteSLV/ }}$

$\S_{\text {https: //twitter.com/MedioAmbienteSV }}$
}

is currently the most practical and useful communication strategy and allows the rapid dissemination of information to people who could be potentially threatened. In addition, regular training sessions are held for the inhabitants of the villages and cities under volcanic threat. Workshops are conducted displaying infographics and hazard maps, and networks of local observers are trained as an important component of Early Warning Systems (EWS).

The EWS can be defined as the set of procedures and instruments through which a threat or adverse event (natural or anthropogenic) of a foreseeable nature is monitored, data and information are collected and processed, offering temporary forecasts and possible effects. According to the International Strategy for Disaster Reduction [Wiltshire 2006] an EWS includes four elements: (1) risk knowledge and available hazard maps, (2) monitoring and forecasting of impending events, (3) data processing and dissemination of understandable alerts to political authorities and the general population, and (4) appropriate and timely response capabilities to such alerts. At this point, the networks of local observers play an important role using their knowledge about the volcano to identify changes in volcanic activity and establish direct communication with local and national official institutions (including civil protection, municipalities, and the army) and other inhabitants from the under-risk areas. In summary, volcanic centers are monitored using geophysical and geochemical instruments, data are analyzed, and communication is established with the direction of civil protection and local observers to determine the preventive measures to follow and thus avoid, insofar as is possible, tragedies.

An EWS was implemented in 2016 in response to the eruption of San Miguel volcano. In order to issue an early warning, the observatory, as the scientific entity in charge of monitoring hazards, worked closely with the Dirección General de Protección Civil, who is responsible for issuing national alerts and crisis management. We are currently working on an EWS for Santa Ana volcano. 


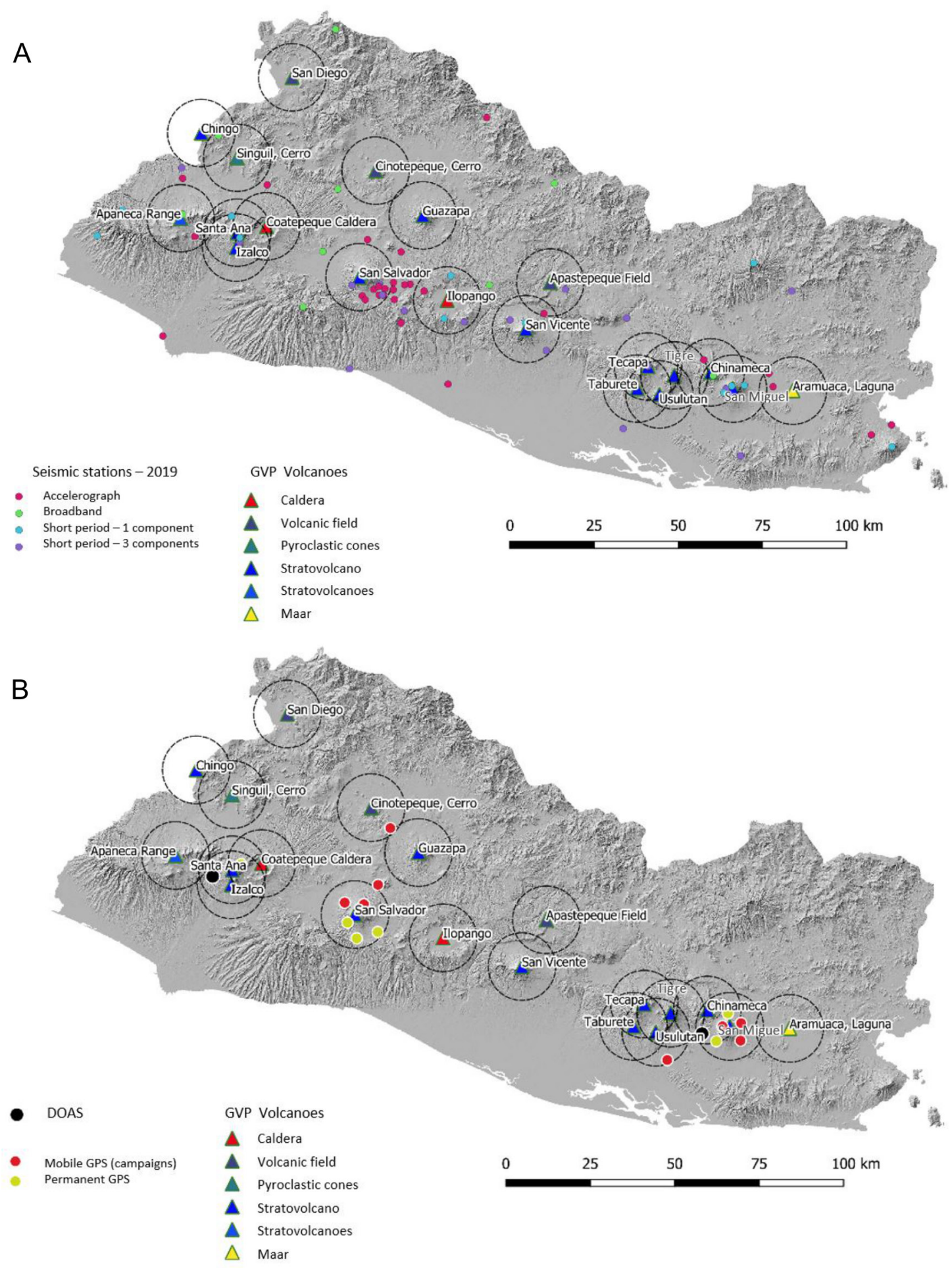

Figure 2: Maps of the monitoring network. [A] Seismic stations, [B] DOAS and GPS stations [MARN 2019a].

5 Needs, Challenges, AND future PerspecTIVES

It will always be the objective to improve and increase the instrumentation coverage of volcanically active areas, but also to maintain and improve the capacity of the expert staff with respect to new techniques and/or technologies.
In order to fulfill the provisions made in the recent preliminary assessment of volcanic threats that prioritize monitoring development, it is necessary to increase monitoring activities at very high and high risk volcanoes. Regarding the amount of instrumentation required for optimal monitoring of San Salvador, Santa Ana, San Miguel and Ilopango volcanoes, it is necessary to acquire more seismic, geodetic, and hydrological in- 

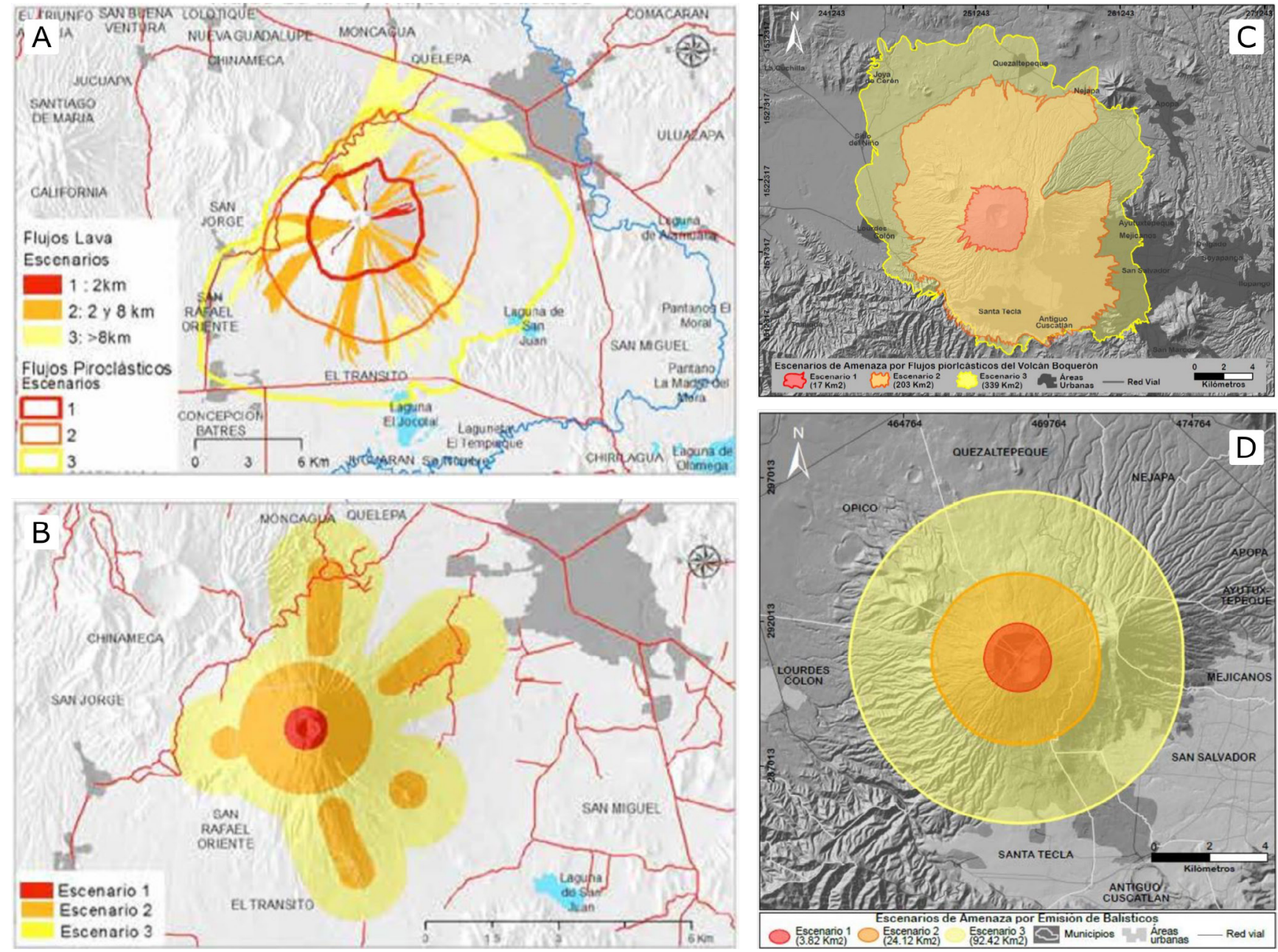

Figure 3: Example of hazard maps for Salvadoran volcanoes according to three different scenarios (small eruptions with high probability in red, moderate eruptions with intermediate probability in orange, and large eruptions with low probability in yellow). [A] Map representing pyroclastic and lava flows hazards for San Miguel volcano [Escobar et al. 2004]. [B] Emission of ballistics hazard map for San Miguel volcano [Escobar et al. 2004]. [C] Pyroclastic flow hazard map for San Salvador volcano (also referred as Volcán Boquerón as in the figure, [Ferrés 2014]). [D] Emission of ballistics hazard map for San Salvador volcano [Ferrés 2014].

struments [MARN 2019a].

Other needs and challenges to be addressed in the short and long term, include:

- Generation of hazard maps of San Vicente, Tecapa, Izalco and Coatepeque and Ilopango calderas, and updating the current hazard maps, using a probabilistic approach. Hazard maps are currently being prepared for Santa Ana, San Salvador, and San Miguel volcanoes.

- Dissemination of hazard maps to the population and training of the public in their interpretation.

- Construction of probabilistic event trees for each volcano, based on available data.

- Development of Early Warning Systems at San Salvador and Santa Ana volcanoes.
- Rigorous conversion of volcanic hazard maps to volcanic risk maps in order to understand the risk level of the areas near volcanoes.

- Strengthening the evaluation of volcanic hazards to better determine how new instruments and techniques can be implemented.

- Conducting physical volcanology studies of the deposits of previous eruptions to estimate frequency, volumes and geochronology of eruptive events in the geological past of El Salvador.

- Strengthening of the existing volcanic monitoring network and developing new monitoring capabilities by adding more instruments and incorporating new technologies [MARN 2019a].

- Finally, identifying evolving hazards in real time to facilitate the issuing of early warnings, with the 
goal of better protecting the populations most at risk

\section{Acknowledgements}

Thanks to co-workers of the natural resources and hazards observatory, especially the area of volcanology for providing important information and documents for the preparation of this article.

\section{Author contributions}

R. Castro and E. Gutiérrez wrote the manuscript.

\section{Data aVailabiliti}

Most of the information presented in this article, as well as other related or complementary information is available on the official websites of the Ministry of the Environment. Total or partial reproduction of the information is allowed, with appropriate source attribution.

\section{Copyright NOTICE}

(C) The Author(s) 2021. This article is distributed under the terms of the Creative Commons Attribution 4.0 International License, which permits unrestricted use, distribution, and reproduction in any medium, provided you give appropriate credit to the original author(s) and the source, provide a link to the Creative Commons license, and indicate if changes were made.

\section{REFERENCES}

Alatorre-Ibargüengoitia, M. A. (2003). "Fisica de proyectiles balisticos volcánicos y delimitación de zonas de peligro por su impacto". PhD thesis. Universidad Nacional Autónoma de México.

Alatorre-Ibargüengoitia, M. A. and H. DelgadoGranados (2006). "Experimental determination of drag coefficient for volcanic materials: Calibration and application of a model to Popocatépetl volcano (Mexico) ballistic projectiles". Geophysical Research Letters 33 (11). DoI: 10.1029/2006gl026195.

Bosse, H., W. Lorenz, A. Merino, A. Mihm, K. Rode, M. Schmidt-Thomé, H. Weber, and G. Wiesemann (1976). Carta Geológica de la República de El Salvador (Centroamérica). Tech. rep. Hannover. [Scale 1: 100,000].

Escobar, C. D., D. Ferrés, C. Pullinger, H. DelgadoGranados, I. A. Farraz, and M. A. AlatorreIbargüengoitia (2004). Mapa de escenarios de amenaza del Volcán de San Miguel o Chaparrastique. Tech. rep. San Salvador. [Scale 1: 200,000].
Ferrés, D. (2014). "Estratigrafıa, geologıa y evaluación de peligros volcánicos del complejo volcánico de San Salvador (El Salvador". PhD thesis. Universidad Nacional Autónoma de México.

Ferrés, D., H. Delgado-Granados, R. E. Gutiérrez, I. A. Farraz, E. W. Hernández, C. R. Pullinger, and C. D. Escobar (2013). "Explosive volcanic history and hazard zonation maps of Boquerón Volcano (San Salvador volcanic complex, El Salvador)". Understanding Open-Vent Volcanism and Related Hazards. Ed. by W. I. Rose, J. L. Palma, H. Delgado-Granados, and N. Varley. Geological Society of America, pp. 201-230. DOI: $10.1130 / 2013.2498(12)$.

Ferrés, D., C. D. Escobar, C. Pullinger, J. Vallance, and J. Griswold (2004). Mapa de Escenarios de Amenaza del Volcán de Santa Ana. Tech. rep. San Salvador. [Scale 1: 200,000].

Geophysical Mass Flow Group [GMFG] (2007). Titan2D User Guide. Tech. rep. New York.

Global Volcanism Program (2020). "Holocene Volcano List". Volcanoes of the World, v. 4.9.1. Ed. by E. Venzke. Smithsonian National Museum of Natural History. Dor: $10.5479 / \mathrm{si}$. GVP. VOTW4-2013.

- (2013). Volcanoes of the World, v. 4.7.1. Venzke, E (ed.). Smithsonian Institution. [Web; Downloaded 07-022021].

Hotovec-Ellis, A. and C. Jeffries (2016). "Near realtime detection, clustering, and analysis of repeating earthquakes: Application to Mount St. Helens and Redoubt volcanoes". Seismological Society of America Annual Meeting. Reno.

Hurst, A. W. (1994). ASHFALL-a computer program for estimating volcanic ash fallout. Tech. rep. Wellington, p. 22.

Jimenez, D., L. Becerril, S. Bartolini, and J. Martí Molist (2018). "Assessing spatial and temporal probabilities in San Miguel Volcano, El Salvador". (Geo3Bcn) Comunicaciones congresos.

Kattan, C., L. Menjivar, G. Molina, Y. Peñate, A. Estrada, I. Moran, T. Chávez, B. Arriola, D. Cruz, R. Vides, C. Canales, M. Diaz, E. Gutierrez, D. Hernández, G. Marroquín, F. Gavidia, L. García, P. Ayala, R. Cerón, A. Erazo, H. Beltrán, C. Rivas, G. Barrera, and A. Cañas (2017). Informe Nacional del Estado de los Riesgos y Vulnerabilidades, San Salvador. San Salvador.

Major, J., S. Schilling, C. Pullinger, C. Escobar, C. Chesner, and M. Howell (2001a). Lahar-hazard zonation for San Miguel volcano, El Salvador. Dor: 10.3133/ ofre1395.

Major, J., S. Schilling, C. Pullinger, C. Escobar, and M. Howell (2001b). Volcano-hazard zonation for San Vicente volcano, El Salvador. DoI: 10.3133/ofre1367.

Major, J., S. Schilling, D. Sofield, C. Escobar, and C. Pullinger (2001c). Volcano hazards in the San Salvador region, El Salvador. Dor: 10.3133/ofre1366.

Malin, M. C. and M. F. Sheridan (1982). "ComputerAssisted Mapping of Pyroclastic Surges". Science 217 
(4560), pp. 637-640. Dor: 10.1126 / science . 217 . 4560.637.

Meyer-Abich, H. (1956). "Los Volcanes Activos De Guatemala Y El Salvador (America Central)". Anales del Servicio Geológico Nacional 3.

Ministerio de Medio Ambiente y Recursos Naturales [MARN] (2019a). Evaluación preliminar de Amenaza Volcánica en El Salvador y Análisis de Brechas "TAGA”, San Salvador.

- (2019b). Monitoreo volcánico. URL: http : / / www . marn . gob.sv / monitoreo - volcanico/ (visited on 11/22/2020).

Pedrazzi, D., I. Sunye-Puchol, G. Aguirre-Diaz, A. Costa, V. C. Smith, M. Poret, P. Dávila-Harris, D. P. Miggins, W. Hernández, and E. Gutiérrez (2019). "The Ilopango Tierra Blanca Joven (TBJ) eruption,
El Salvador: Volcano-stratigraphy and physical characterization of the major Holocene event of Central America". Journal of Volcanology and Geothermal Research 377, pp. 81-102. Dor: 10.1016/j . jvolgeores. 2019.03.006.

Pitman, E. B., C. C. Nichita, A. Patra, A. Bauer, M. Sheridan, and M. Bursik (2003). "Computing granular avalanches and landslides". Physics of Fluids 15 (12), pp. 3638-3646. Dor: 10.1063/1.1614253.

Siebert, L., T. Simkin, and P. Kimberly (2011). Volcanoes of the World. Univ of California Press. ISBN: 9780520268777.

Wiltshire, A. (2006). "Developing early warning systems: a checklist". Proc. 3rd Int. Conf. Early Warning (EWC). ISDR/ Federal Foreign Office, pp. 27-19. 